DOI: 10.20472/TEC.2019.008.004

\title{
ZEYNEP AYDEMIR
}

MARMARA UNIVERSITY, Turkey

NURAY BAŞPINAR

Ministry Of National Education, Turkey

\section{THE EFFECT OF PRE-TEXT QUESTIONS ON PREPARING STUDENTS FOR THE TEXT}

\begin{abstract}
:
In order to enable the students to reach the determined goals, while preparing questions based on the texts, the questions should be grouped into the questions to be asked before the text, the questions to be asked while the text is processed and the questions to be asked after the text is processed, and the levels of these questions should be organized according to the performance of the students. Akyol (1997) defines the limitations of the text preparation questions as "pre-text questions can limit the understanding of the reader because the reader can only read to find the answers to the questions "; while the advantages of these questions " "pre-text questions arouse curiosity about the material to be read by the student; It focuses its attention on specific information and makes it easier to make accurate interpretations of what might happen next stage". Based on these approaches, this research was aimed to examine the effect of pre-text questions on preparing students for the text. 60 (29 male, 31 female) students of the second grade students in Sancaktepe district of Istanbul participated in the study. In the study, which was designed according to the case study of qualitative research patterns, as a data collection tool, student worksheets consisting of pre- and post-text questions prepared by the researchers, observation notes and semi-structured interview form were used. The practice was carried out with two narrative texts prepared with $5 \mathrm{~W}-1 \mathrm{H}$ questions (the first text formed by giving $5 \mathrm{~W}-1 \mathrm{H}$ questions before the text, the second text formed by giving $5 \mathrm{~W}-1 \mathrm{H}$ questions after the text) and the form of "I Choose Worksheet" after the course. Content analysis was used to analyze the collected data. As a result of the findings, it was observed that the students wanted to ask questions about the pre-text, the questions asked led them to understand the text better and they preferred the text consisting of pre-text questions.
\end{abstract}

\section{Keywords:}

Pre-text questions, post-text questions, $5 \mathrm{~W}-1 \mathrm{H}$ questions, narrative text, preparation for the text. 


\section{Introduction}

Reading, vision, vocalization, understanding, structuring in the mind, such as eye, voice and our brain is formed as a result of various complex activities. First certain lines, letters or symbols to be detected, after understanding the meaning of those words and phrases by concentration of attention in this regard and by way of embodying the memory reaches process success. Reading comprehension is a cognitive skill that measures the reader's ability to combine text knowledge with previous knowledge and results in the details of the individual's mental goal (Anderson \& Pearson, 1984; Afflerb ach, 1990; Meneghetti, Carretti \& Dee Me, 2006). Hence, reading comprehension is an interactive process between the reader and the text (Rumelhart, 1994). In order to reach a successful level of understanding, the reader and the text elements should be examined ( $\mathrm{Au}$, Highfield \& Raphael, 2006). Recent research states that children should focus more on understanding and content in texts they read rather than learning to make meaning (Neuman, 2001).

In his book "Literacy", Paulo Freire described "the act of reading as remembering the distant childhood as far as I could trust, trying to understand the special world and the act of reading in which I act, absolutely meaningful to me". Making reading and understanding meaningful for students depends on the interaction between the text and the reader. One of the most important tools used to make sense is questions. Researchers (Cerdán, VidalAbarca, Martínez, Gilabert and Gil, 2009; by stated Akyol, Yildirim, Ates and Cetinkaya, 2013) state that the questions deeply affect the understanding process. In order to enable the students to reach the determined goals, while preparing questions based on the texts, the questions should be grouped into the questions to be asked before the text, the questions to be asked while the text is processed and the questions to be asked after the text is processed, and the levels of these questions should be organized according to the performance of the students. (Akyol, 1997). The student can answer the questions of the given text, summarize briefly, and illustrate the events in the text in order of occurrence. If the teacher wants the student to read the text and then explain what he has read, the student will first need to focus his attention on the text. It is thought that the students' attention can be drawn to the text with the help of the questions given before the text. Akyol (1997) defines the limitations of the text preparation questions as "pre-text questions can limit the understanding of the reader because the reader can only read to find the answers to the questions "; while the advantages of these questions " "pre-text questions arouse curiosity about the material to be read by the student; It focuses its attention on specific information and makes it easier to make accurate interpretations of what might happen next stage". 
The questions asked before the text may varies; but when the class starts with questions that explain the content of the story, such as $5 \mathrm{~W}-1 \mathrm{H}$ questions, the student will look for answers to these questions in the text. $5 \mathrm{~W}-1 \mathrm{H}$ questions, what, where, when, how, why and who are frequently encountered in narrative texts. Narrative text is an interesting, intriguing text that is used to explain and explain an event or situation in a cause and effect relationship. The types of narrative texts attract children's interest more (Lüle Mert, 2012). The student will be motivated to read the text by establishing a cause and effect relationship to answer the $5 \mathrm{~W}-1 \mathrm{H}$ questions. Motivation, which is a concept related to learning, is defined as the force that activates, maintains and directs the behavior towards a goal. Motivation is the most important determinant of success and efficiency by initiating and sustaining the action (Dilekmen \& Ada, 2005). Reading is a skill that requires students to choose between doing and not doing. This requires motivation. Motivation students' attitudes towards reading, interest and so on. positively affects many behavioral characteristics.

The relevant readers are motivated to read in a variety of ways, creating new insights from the knowledge gained from their previous experience. Thus, they participate in different social interactions through reading (Aydemir \& Ozturk, 2013). Therefore, it is useful to ask certain questions before the text in order to direct the student's attention to the text and motivate them. Motivating all students in the light of certain questions means providing the opportunity to look at the text in a common framework. The student will find the answers to the questions sought in the text by interpreting the words in the text. On the other hand, pre-text questions are answered by the student while reading the text, and can be checked again after reading the text. The answers of the questions are repeated at least three times by the student.

The reader can go over the same sentence over and over, weigh its meaning, and analyze every kind of meaning by analyzing its structure. A sentence can be divided into particles and distilled until the last real drop is reached (Sanders, 1994). According to Sanders, it is important again in reading. Techniques for assisting and developing children's reading and comprehension skills and motivating children to do more reading have always been of interest to educators and those involved in educational research. Therefore, if we want to increase the level of reading and in connection with this, it is very important to ensure the active participation of the student. If the student learns what is expected of him / her at the beginning of the text, he/she will endeavor to realize this learning. The student will increase his interest in reading as he understands what he is 
reading, and as his reading skill increases, he may become more fond of reading. Therefore, the activities planned by the teacher are extremely important for achieving the set goals. Based on these approaches, the number of studies on pre-text questions is small. The aim of this study is to examine the effect of pre-text questions on preparing students for the text in order to make detailed analysis of pre-text questions. Research questions are as follows:

1. What are the pre-text and post-text question preferences of the students?

2. What are the reasons for pre-text and post-text questions?

\section{Method}

In this section, the research model that constitutes the research method, the working group, the data collection and the analysis of the data are given.

\section{Research model}

In the study, holistic (single) case design was used from the case study which is a qualitative research design. Based on the aspects separated from other types of research, it is possible to say that the case study is a research method based on the 'how' and 'why' questions, allowing the researcher to investigate in depth the phenomenon or event that the researcher cannot control (Yıldırım \& Şimşek, 2016 ) .

\section{Participants}

The study group consisted of 60 (29 boys, 31 girls) students from the second grade students of a primary school in Sancaktepe district of Istanbul

\section{Data collection tools}

In the research, the student worksheets consisting of pre- and post-text questions prepared by the researchers and semistructured interview form were used as data collection tools.

The study prepared by researchers, data collection instruments are as follows:

"I choose my worksheet" semi-structured interview form

Worksheet of text consisting of questions before $5 \mathrm{~W}-1 \mathrm{H}$ text that "The Crow and the Fox"

Worksheet of text consisting of questions after $5 \mathrm{~W}-1 \mathrm{H}$ text that "The Crow and the Fox"

Worksheet of text consisting of questions before $5 \mathrm{~W}-1 \mathrm{H}$ text that " Sun and Wind "

Worksheet of text consisting of questions after $5 \mathrm{~W}-1 \mathrm{H}$ text that " Sun and Wind"

\section{Data Collection}

The first group was given Crow and Fox, which consisted of pretext questions, and Sun and Wind, which consisted of post-text 
questions, respectively. The students were asked to read the text quietly and answer the questions. Afterwards, the group was given a 'I Choose My Worksheet' form and asked which text they liked more and a brief summary of the texts was asked.

The second group was given Sun and Wind, which consisted of pre-text questions, and, Crow and Fox which consisted of posttext questions, respectively. Afterwards, the form was distributed to the group with the form of "I Choose My Worksheet" and asked which text he liked more and a brief summary of the texts was asked. The purpose of this study is to ensure that the content of the text is examined independently of the content of the text.
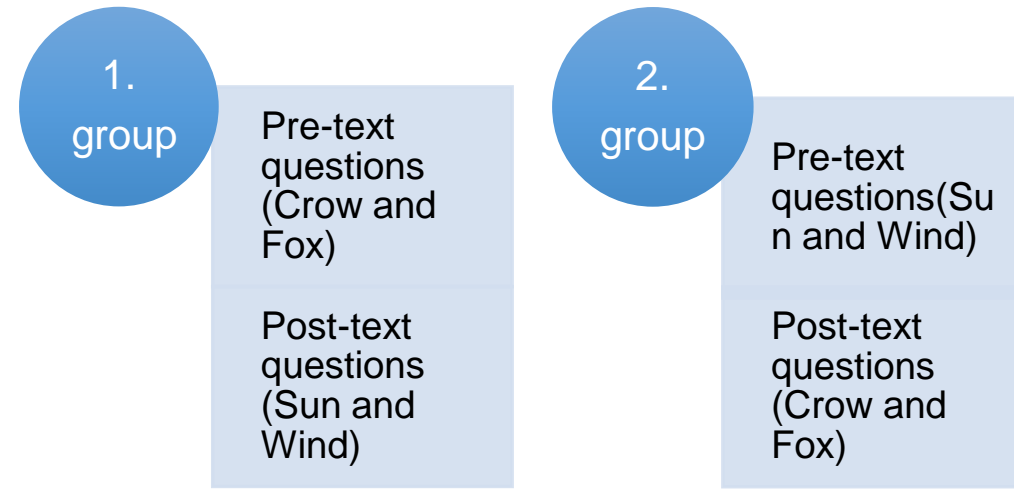

Figure 1: “I choose my worksheet" form

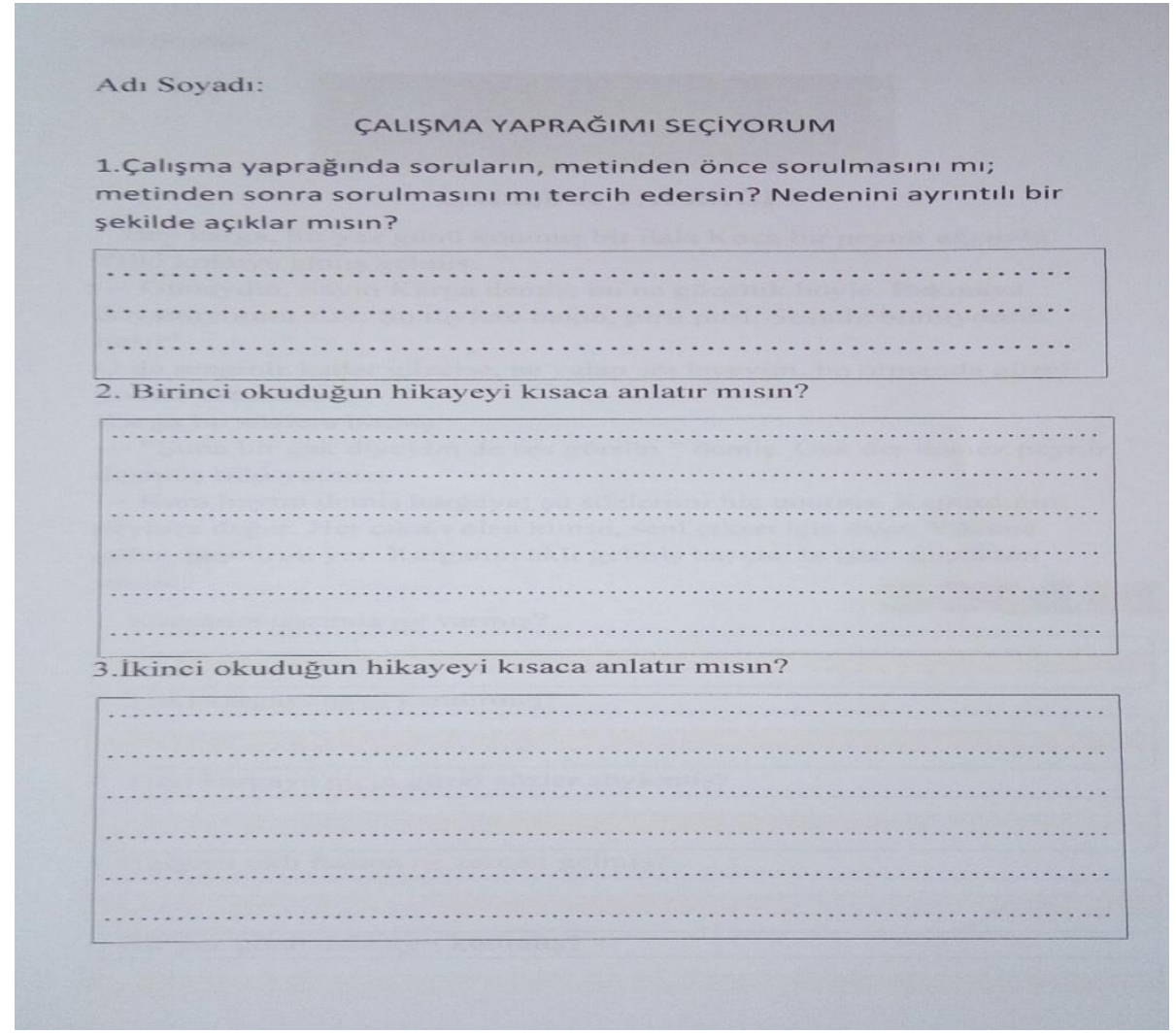


With the "I Choose My Worksheet" form, the students were asked to explain which of the given texts they prefer and why, and give a short description of the texts they read.

Figure 2: Two Worksheets Given to 1.Group Students (Text 1 and Text 2)

Adı Soyad:
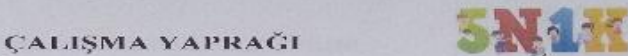

1. Karganın ağgenda ne varmıs?
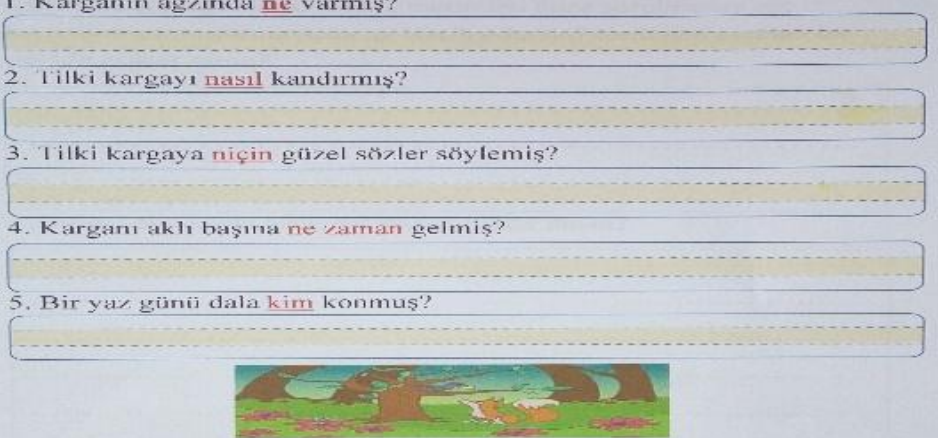

Bay karga, bir yaz günü konmus bir dala Koca bir peynir aggzında, Tilki kokuyu almis gelmis

- Günaydun, Saym Karqa demiş; hu ne güzellik bëyle. Bakmaya

doyamyorum size. Su tüylere bakın, piril pırıl. Sesiniz bilmiyorum nasıll? O da renginiz kadar puzelsc, no yalan söyleyeyim, bu ormanda güzel yoktur

Karga bu sözlere bitmis:

"Şuna bir gak diyeyim de ses görsün." demis. Gak der demez poynir düsmüs tilki yutmus

Kara bayım demis kargaya; șu sözlerimi hiç unutma. Kaptırdığın peynire deñer. Her cıkarı olan kimse, seni cıkarı için över. Yüzïne güler, peynirini

yer. Kargamm akh gelmiş bașına. Is ișten geçtikten sonra.

Ad Soyad1:

\section{CALISMA YAPRAG}

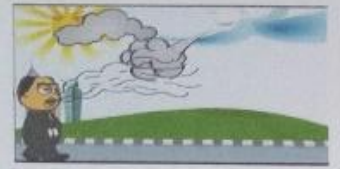

Güneş ve rüzgâr, bir yaz günü kimin daha güçlü olduğunu tartıșıyorlarmıs. Rüzgâr: -Ben daha güçlü olduğumu kanıtlayacağım Su karşıdaki yolda yürüyen paltolu yașlı adamı görüyor musun? Paltosunu senden daha hızı çıaracağıma bahse girerim

demiş. Güneş bir bulutun arkasına çekilmiş ve rüzgâr kasırga şiddetinde esmeye bașlamıs. O kuvvetle estikçe ihtiyar adam paltosuna daha sıkı sarılıyormuș.

Sonunda rüzgâr pes edip durmuş. Güneș bulutların arkasından çıkıp yaşlı adama nazikçe gülümsemiș. Cok geçmeden adam alnındaki teri silip paltosunu çıkarmıs.

Sonra, rüzgâra dönmüs nazik ve dostça davranıșın, şiddet ve güç gösterisinden daha etkili olduḡunu söylemis.

1. Razgâr, adamin paltosunu cıkarmak için ne yapmış?

2. Rüzgar adamm paltosunu çıkarmak için nasıl esmiştir?

3. Günes ve rüzgâr neden tartıșıyormuş?

4. Güncs ve rüzgâr ne zaman tartışmışlar?

Parçada kimler tartıșıy ormus?

6. Adam nerede yärüyormus? 


\section{Figure 3: Two Worksheets Given to 2.Group Students (Text 1} and Text 2)

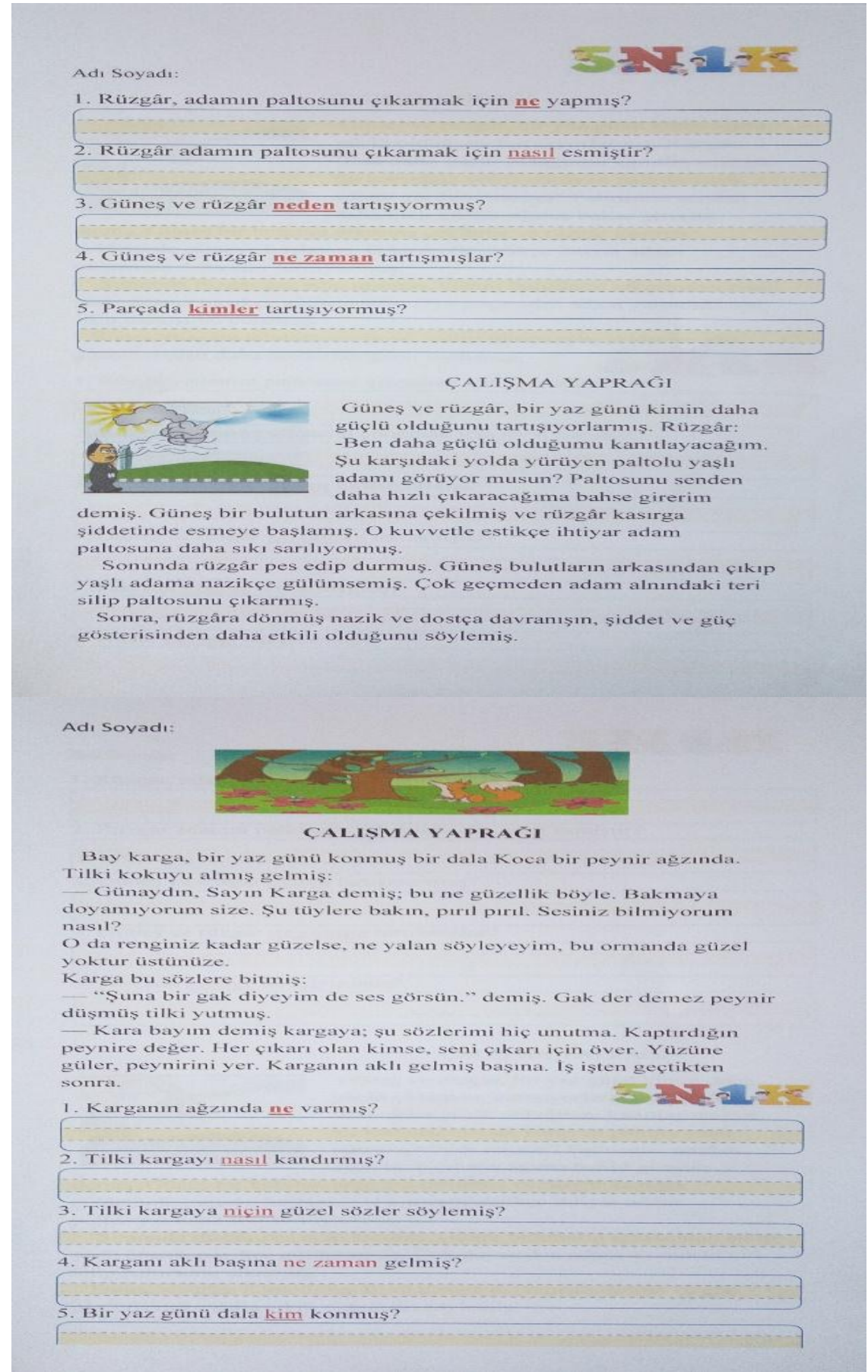

\section{Analyses of data}

Pre-text and post-text preference numbers in the 'I Choose My Worksheet' form were analyzed. The reasons in their selection were grouped under two categories (Those who stated why, those who did not specify) and the frequency values were calculated. The content of the short summaries in the same form in terms of the meaning of the text before and after the text in the summary of the text was analyzed by content analysis. 


\section{Findings}

What are the pre-text and post-text question preferences of the students?

When the students were asked whether they chose the worksheets that continued with the text that started with the questions before, the worksheet that was continued with the questions after the text, 39 students stated that they liked to be asked the questions before the text and 21 students liked to be asked the questions after the text.

Table 1: Number of pre-and post-text preferences of students

\begin{tabular}{ll}
\hline $\begin{array}{l}\text { Preference } \\
\%\end{array}$ & $\mathrm{~N}$ \\
\hline Text preferences consisting of pre-text questions & 39 \\
65 & \\
$\begin{array}{l}\text { Text preferences consisting of post-text questions } \\
35\end{array}$ & 21 \\
$\begin{array}{l}\text { Total } \\
100\end{array}$ & 60 \\
\hline
\end{tabular}

As shown in Table 1,65\% of the students preferred worksheets with pre-text questions. It has been observed that there is no significant difference in each narrative text of the student

What are the reasons for pre-text and post-text questions?

According to the results of the research, the reasons for choosing students are given in Table 2.

Table 2: The reasons what students prefer pre -text and posttext questions

\begin{tabular}{llll}
\hline Pre-Text Questions & f & Post-Text Questions & f \\
\hline Students who state a reason & & Students who state a reason & \\
\hline Understanding better & 10 & Understanding better & 5 \\
Gives hint & 6 & Look at the text & 4 \\
Beautiful & 3 & Questions to answer quickly & 1 \\
Looking at the questions again & 2 & & \\
Quickly understand & 1 & & \\
Guess the questions & 1 & & \\
Having fun & 1 & & \\
Seems different & 1 & & \\
Easy & 1 & & \\
Be knowledgeable about & 1 & & \\
Funny & 1 & & \\
\hline Students who do not state a reason & 9 & Students who do not state a reason & \\
& & & \\
Total & 39 & & \\
\hline
\end{tabular}

According to the majority of the answers received from the students, the main reason for choosing pre-text questions is to understand the text better. In addition, one of the reasons for 
choosing texts that start with questions is that they understand the text better because they give clues about the text and can solve the questions more carefully. On the other hand after the text that questions the students who prefer the text 'text can not solve the questions without reading' more like circulation from previous habit years before the text it after the text of the tuft and questions to arrive gun that objective has said.

\section{Conclusion, Discussion and Suggestions}

The students were asked whether they preferred to be asked before the text or after the text and why. The students who chose to be asked questions before the text stated that they understood the text better, that they had clues about the text, that they guessed what was described in the text and that they liked the text to start with the question. Akyol (2001) stated that, although the pre-text questions had the feature of preparing the text by making the pre-knowledge effective, no pre-text questions were included in the book prepared by the Ministry of National Education and the pre-text questions were balanced in the reading boks. The findings of the study support this opinion. With the preparation questions to the students; the subject of the text is prepared from the cognitive and affective aspects, Attention is drawn to the subject, Motivated, they need to learn the subject becomes. Durkin (1981), on the other hand, emphasized that the questions about the preparation of the text increased what was learned about the subject (by stated Ensar, 2002). Van Den Broek, Kendeou, Lousberg and Visser (2011) indicate that such interventions are indeed feasible. Moreover, they suggest that for both toddlers and early readers questions during comprehension are more effective than questions after comprehension at their research that with Early readers (3rd grade) and even toddlers (23 years old). Mujahidah and Ramli (2019) present article intended to investigate the effectiveness of pre reading plan (PReP) technique to improve student's reading comprehension of narrative text at one senior high school in Pinrang, South Sulawesi of Indonesia. Mujahidah and Ramli (2019) claim that the study found out that the students' reading comprehension had increased after doing the learning process by using pre reading plan (PReP) technique. This finding supports the findings of the study.

Some of the students who wanted to be asked questions after the text stated that they understood the text better and preferred it because they answered the questions according to the text. In his study, Akyol (2001) stated that repeating the facts described in the text by asking questions by memorization would not improve the skills of meaningful learning, critical thinking, and writing answers based on questions. If post-text questions are to be 
asked, children should also be asked questions of the kind in which they can use their own ideas .

As a result, $65 \%$ of the students preferred to give the pre-text questions.

This study shows that:

- The development of literacy skills can be supported by questions.

- If the student who has difficulty understanding what he / she reads is asked questions about the pre-text questions, he / she can catch clues about the text and make it easier for the student to understand the text .

- A student who is not interested in the text can be made willing with questions.

- Students with slow comprehension can be given time to understand the text with pre-text questions.

- Post- text questions can be created differently from conventional question patterns.

\section{References}

Akyol, H. (1997). Classification of Questions in Reading Texts. Education and Science, 21 (105), pp. 10-17.

Akyol, H. (2001). Analysis of the questions related to reading texts in primary school 5th grade Turkish textbooks. Educational Administration in Theory and Practice, pp. 170-178.

Akyol, H., Yıldırım, K., Ateş, S. \& Çetinkaya, Ç. (2013). What kinds of questions do we ask for making meaning? Mersin University Journal of the Faculty of Education, Vol. 9, Issue 1, April 2013, pp. 41-56.

Anderson, R. C., \& Pearson, D. (1984). A schema-thematic view of basic processes in reading comprehension. In P. D. Pearson, R. Barr, M. L. Kamil, \& P. Mosenthals (Eds.), Handbook of Reading Research (pp. 255 - 291). New York: Longman.

Afflerbach, P. (1990). The influence of prior knowledge and text genre on readers' prediction strategies. Journal of Reading Behaviour, 22, 131-148.

Au, K. H. \& Raphael, T. E. (2005). QAR: enhancing comprehension and test taking across grades and content areas. The Reading Teacher, 59(3), 206-221.

Aydemir, Z. \& Ozturk, E. (2013). Reading Motivation Scale for Texts: Validity and Reliability Study. Elementary Education Online, 12 (1), 66-76, 2013.

Dilekmen, M. \& Ada, Ş. (2005). Motivation in learning. Kazım Karabekir Journal of Education Faculty, Issue: 11.

Ensar, F. (2002). A Review on Six Text Questions in Primary School 6th Grade Turkish Textbooks. Ankara: Gazi University Institute of Educational Sciences Department of Turkish Education (Unpublished Master Thesis). 
Freire, P. \& Macedo, D. (1998). Literacy Words and Reading the World. (Translated by Ayhan). Ankara: Imge Bookstore.

Lüle Mert, E. (2012). Examining the stories in primary school 6th, 7th and 8th grade Turkish textbooks in the context of basic principles of children's writing. Amasya University Journal of the Faculty of Education, 1 (1), 73-93.

Meneghetti, C., Carretti, B., \& De Beni, R. (2006). Components of reading comprehension and scholastic achievement. Learning and Individual Differences, 16, 291-301.

Mujahidah, M. \& Ramli, R. (2019). Effectiveness of Pre Reading Plan (PReP) Technique to Improve Student's Reading Comprehension of Narrative Text. Jurnal Bahasa dan Linguistik Vol. 8 No. 2: Hal. 91-100, DOI: https://doi.org/10.33506/li.v8i2.376.

Neuman, S.B. (2001). The role of knowledge in early literacy. Reading Research Quarterly, 36(4), 468-475.

Rumelhart, D. E. (1994). Toward an interactive model of reading. In R. Rudell, M. R. Rudell, \& H. Singer (Eds.), Theoretical models and processes of reading (4th ed.) (pp. 864 - 894). Newark, DA: International Reading Association.

Van Den Broek, P., Kendeou, P., Lousberg, S. \& Visser, G. (2011). Preparing for reading comprehension: Fostering text comprehension skills in preschool and early elementary school children. International Electronic Journal of Elementary Education, 2011, 4(1), 259-268. 